\title{
Enzymatic and biochemical characterization of Bungarus sindanus snake venom acetylcholinesterase
}

Ahmed M (1), Latif N (2), Khan RA (1), Ahmad A (1), Rocha JBT (2), Mazzanti CM (2), Bagatini MD (2), Morsch VM (2), Schetinger MRC (2)

(1) Department of Biotechnology, University of Science and Technology, Bannu, Kyber Pakhtunkhwa, Pakistan; (2) Department of Biochemistry and Toxicology, Center of Natural and Exact Sciences, Federal University of Santa Maria, Santa Maria, Rio Grande do Sul State, Brazil.

\begin{abstract}
This study analyses venom from the elapid krait snake Bungarus sindanus, which contains a high level of acetylcholinesterase (AChE) activity. The enzyme showed optimum activity at alkaline $\mathrm{pH}(8.5)$ and $45^{\circ} \mathrm{C}$. Krait venom AChE was inhibited by substrate. Inhibition was significantly reduced by using a high ionic strength buffer; low ionic strength buffer $\left(10 \mathrm{mM} \mathrm{PO}_{4} \mathrm{pH} 7.5\right)$ inhibited the enzyme by $1.5 \mathrm{mM} \mathrm{AcSCh}$, while high ionic strength buffer $\left(62 \mathrm{mM} \mathrm{PO}_{4} \mathrm{pH} 7.5\right)$ inhibited it by $1 \mathrm{mM} \mathrm{AcSCh}$. Venom acetylcholinesterase was also found to be thermally stable at $45^{\circ} \mathrm{C}$; it only lost $5 \%$ of its activity after incubation at $45^{\circ} \mathrm{C}$ for 40 minutes. The Michaelis-Menten constant $(\mathrm{Km})$ for acetylthiocholine iodide hydrolysis was found to be 0.068 $\mathrm{mM}$. Krait venom acetylcholinesterase was also inhibited by $\mathrm{ZnCl}_{2}, \mathrm{CdCl}_{2}$, and $\mathrm{HgCl}_{2}$ in a concentrationdependent manner. Due to the elevated levels of AChE with high catalytic activity and because it is more stable than any other sources, Bungarus sindanus venom is highly valuable for biochemical studies of this enzyme.
\end{abstract}

Key words: acetylcholinesterase, inhibition, krait, ionic strength, acetylthiocholine iodide, Bungarus sindanus, snake venom.

\section{INTRODUCTION}

Acetylcholinesterase is present in all vertebrates, particularly in the muscles and nervous tissues (1). Structurally and functionally acetylchloinesterase is a serine hydrolase (AChE, acetylcholine hydrolase, EC. 3.1.1.7). The enzyme is found in both synaptic and non-synaptic tissues (1-3). In synaptic tissue the main role of acetylcholinesterase is the hydrolysis of neurotransmitter acetylcholine (ACh). The catalytic activity of this enzyme is essential for normal cholinergic transmission and neuromuscular function (4).

In a non-synaptic context, AChE and BChE are expressed in early embryonic development some time before the formation of cholinergic synapsis, where its function is the formation and regulation of the acetylcholine gradient which guides the growth of nerve cells (5-7). A noteworthy amount of acetylcholinesterase is also present in blood cells, particularly in erythrocytes and lymphocytes $(8,9)$. The most common nonsynaptic example is snake venom, in which its function is unknown $(10,11)$. In snake venom, acetylcholinesterase exists in all Elapidae venom except mambas (12). Recent literature indicates that acetylcholinesterase is also present in nonpoisonous snake venoms (13).

The Bungarus genus of Elapidae is well-known due to the large amount of acetylcholinesterase, about $8 \mathrm{mg} / \mathrm{g}$ in dried venom $(0.8 \% \mathrm{w} / \mathrm{w})$, which is highly active (> 60,000 Elman units/mg) (10). Although highly active, it is non-toxic even when 
tested at high concentrations (14). The enzyme reaction catalyzed by acetylcholinesterase is one of the most efficient reactions. Partial peptide sequence studies show that snake venom enzymes have close homology with other acetylcholinesterases, and have the same catalytic triad for substrate hydrolysis (14). The efficiency of substrate hydrolysis could be related to threedimensional structures of the enzyme. The long narrow active site gorge is $20 \AA$ deep, composed of two subsites for ligand interaction: an acylation site at the base of the gorge with a catalytic triad and peripheral site at its mouth, distinct from a catalytic active site $(15,16)$.

Previously, we found that Bungarus sindanus venom $A C h E$ is inhibited by commonly used pesticides and herbicides with inhibitory behavior similar to human serum BChE (17). Furthermore, krait (Bungarus sindanus) venom enzyme shows high sensitivity towards tacrine, commonly use in treating Alzheimer's disease (18). However snake venom acetylcholinesterase is different from other vertebrate tissues since it is present in soluble non-amphiphilic monomeric form (14). This study was designed to discover more about krait venom AChE in terms of thermal stability, substrate specificity, and substrate inhibition, and the effects of ionic buffer strength, $\mathrm{pH}$, temperature, and metals.

\section{MATERIALS AND METHODS}

\section{Materials}

Acetylthiocholine iodide, butyrylthiocholine iodide, DTNB [5,5'-dithiobis(2-nitro-benzoic acid)], bovine serum albumin, and Coomassie Brilliant blue R-250 were purchased from Sigma (USA). Sodium dihydrogen phosphate and disodium hydrogen phosphate were purchased from Neon Comercial LTDA (Brazil); and Tris (hydroxymethyl amino methane) from Vetec (Brazil). All other reagents used were of analytical grade.

\section{Venom}

Venom from live Bungarus sindanus snakes was manually milked, immediately lyophilized and stored at $-20^{\circ} \mathrm{C}$ for future use.

\section{Protein Determination}

Protein was assayed according to Bradford (19) using bovine serum albumin as standard.

\section{Statistical Analysis}

Statistical analysis was performed using one way ANOVA, followed by post-hoc analysis (Duncan multiple range test).

\section{Cholinesterase Assay}

Cholinesterase activities were determined according to Ahmed et al. (20) with some modifications Rocha et al. (21). Hydrolysis rates (V) were measured at various acetylthiocholine (S) concentrations $(0.05$ to $3 \mathrm{mM})$ in $1-\mathrm{mL}$ assay solutions with $10 \mathrm{mM}$ phosphate buffer, $\mathrm{pH} 7.5$, and $0.2 \mathrm{mM}$ DTNB at $25^{\circ} \mathrm{C}$. Snake venom $(40 \mu \mathrm{L}$ equivalent to $1 \mu \mathrm{g}$ of protein) were added to the reaction mixture and pre-incubated for 30 minutes at $37^{\circ} \mathrm{C}$. We did not find butyrylcholinesterase in the crude venom so we did not use ethopropazine (a specific butyrylcholinesterase inhibitor) in any of the enzyme essays. Hydrolysis was monitored by verifying the formation of the thiolate dianion of DTNB at $412 \mathrm{~nm}$ for 2 to 3 minutes (15 second intervals) using a using Hitachi U-2001 spectrophotometer (Tokyo, Japan). All samples were run in duplicate or triplicate.

\section{$\mathrm{K}_{\mathrm{m}}$ and $\mathbf{V}_{\max }$ Determination}

The kinetic parameters $\mathrm{K}_{\mathrm{m}}$ and $\mathrm{V}_{\max }$ were determined from Linewear and Burk (22) double reciprocal plot analyzed over a range of acetylthiocholine concentrations (0.05 to $3 \mathrm{mM}$ ). For comparison Hanes-Woolf, Eadie-Hofstee, and Direct Linear Wilkinson plot were used to determine $\mathrm{K}_{\mathrm{m}}$ and $\mathrm{V}_{\max }$ values.

\section{Kinetic Analysis}

Kinetic analysis was performed using Slide Write software.

\section{RESULTS}

Substrate specificity of snake venom acetylcholinesterase (AChE) was evaluated by testing acetylthiocholine (AcSCh) and butyrylthiocholine (BuSCh) as a substrate varying from 0.05 to $3 \mathrm{mM}$. Krait (Bungaraus sindanus) venom $\mathrm{AChE}$ only hydrolyzed acetylthiocholine (AcSCh) (Figure 1).

Substrate kinetic parameters for acetylthiocholine were calculated by double reciprocal Linweaver-Burk plot (Linweaver and Burk, 1934) resulting in $\mathrm{K}_{\mathrm{m}}=0.068 \mathrm{mM}$ and $\mathrm{V}_{\max }=$ $651 \mu \mathrm{mole} / \mathrm{min} / \mathrm{mg}$ protein (Figure 2 ). Calculated 
$\mathrm{K}_{\mathrm{m}}$ and $\mathrm{V}_{\max }$ values by different plots are shown in Table 1. Krait venom AChE was inhibited by substrate. However, substrate inhibition varies with buffer ionic strength. We closely observed that low ionic strength buffer $\left(10 \mathrm{mM} \mathrm{PO}_{4} ; \mathrm{pH}\right.$ 7.5 ) inhibited the enzyme by $1.5 \mathrm{mM}$ substrate while with high ionic strength buffer $(62 \mathrm{mM}$ $\left.\mathrm{PO}_{4} ; \mathrm{pH} 7.5\right)$ venom AChE was more sensitive to substrate inhibition and was inhibited by $1 \mathrm{mM}$ acetylthiocholine (Figure 3).

The enzyme is $\mathrm{pH}$ sensitive and shows higher activity in alkaline media ( $\mathrm{pH}$ 8.5) whilst in acid media ( $\mathrm{pH} 4$ ) the enzyme does not show its hydrolytic property (Figure 4). It does become slightly more active at $45^{\circ} \mathrm{C}$ for substrate hydrolysis (Figure 5). It is also thermally stable compared to electric eel acetylcholinesterase by incubating at $45^{\circ} \mathrm{C}$ for 40 minutes (Figure $5-\mathrm{A}$ ). We found only $5 \%$ loss in venom acetylcholinesterase after 40 minutes at $45^{\circ} \mathrm{C}$, which is far less than electric eel acetylcholinesterase. Electric eel $\mathrm{AChE}$ lost $69 \%$ of its activity after 15 minutes at $45^{\circ} \mathrm{C}$ compared to inhibition at $37^{\circ} \mathrm{C}$. This enzyme lost $80 \%$ of its activity after incubation at $45^{\circ} \mathrm{C}$ for 40 minutes (Figure $5-\mathrm{B}$ ). Bungaraus sindanus venom $\mathrm{AChE}$ is also inhibited by $\mathrm{ZnCl}_{2}, \mathrm{CdCl}_{2}$, and $\mathrm{HgCl}_{2}$ in a concentration dependent manner (Figure 6). Inhibition of krait (Bungarus sindanus) venom $\mathrm{AChE}$ by metals was also confirmed by electrometric method using acetylcholine substrate (data not shown).

Table 1. $K_{m}$ and $V_{\max }$ values from different plots

\begin{tabular}{c|c|c|c|c|c}
\hline & Lineweaver-Burk & Hanes-Woolf & Eadie-Hofstee & Direct linear & Wilkinson \\
\hline$K_{m}$ & 0.068 & 0.0749 & 0.0547 & 0.0576 & 0.0492 \\
\hline$V_{\max }$ & 651 & 635 & 597 & 567 & 587 \\
\hline
\end{tabular}

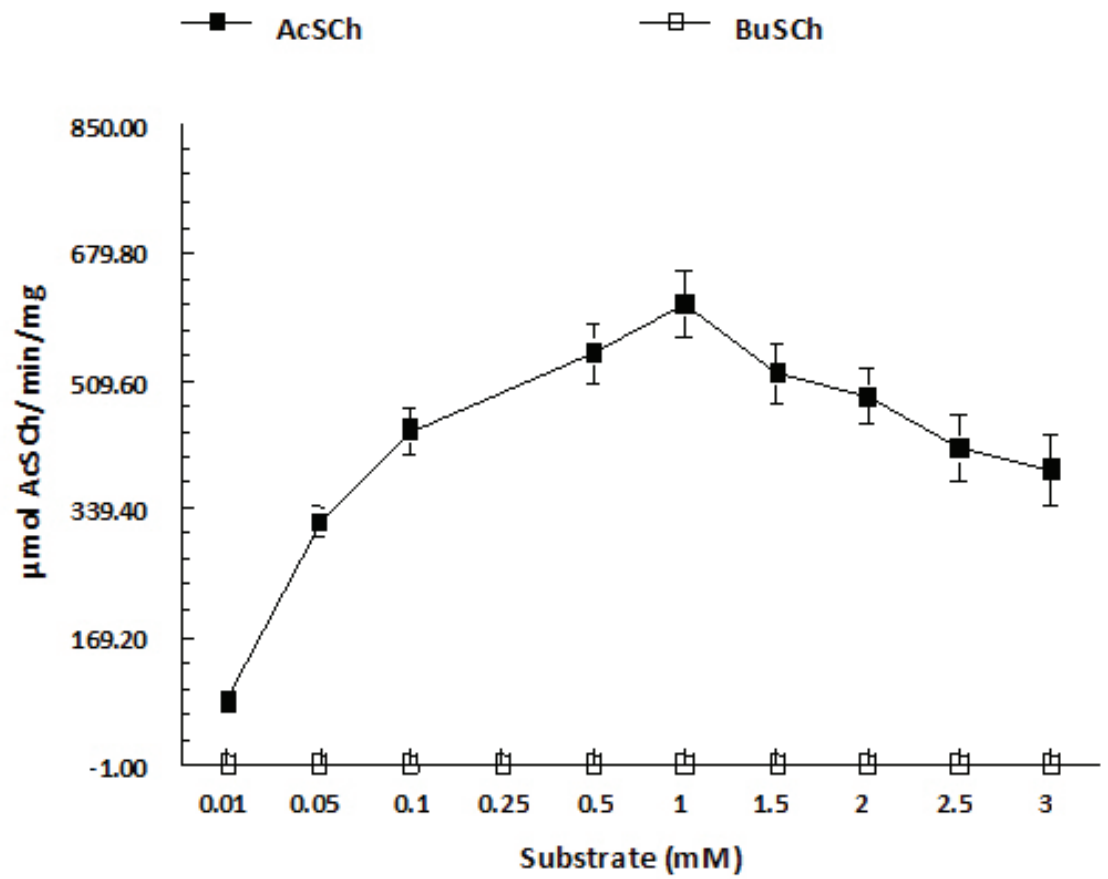

Figure 1. Substrate specificity. Hydrolysis of acetylthiocholine (AcSCh) and butyrylthiocholine (BuSCh) by krait (Bungaraus sindanus) venom AChE. Venom protein $(1 \mu \mathrm{g})$ was preincubated for ten minutes in $1 \mathrm{~mL}$ assay solutions with $10 \mathrm{mM} \mathrm{PO}_{4}$ buffer, $\mathrm{pH}$ 7.5, and $0.2 \mathrm{mM} \mathrm{DTNB}$ [5,5-dithiobis(2-nitrobenzoic acid)] before adding substrate at 0.05 to $3 \mathrm{mM}$. All experiments were repeated at least three times and similar results were obtained. 


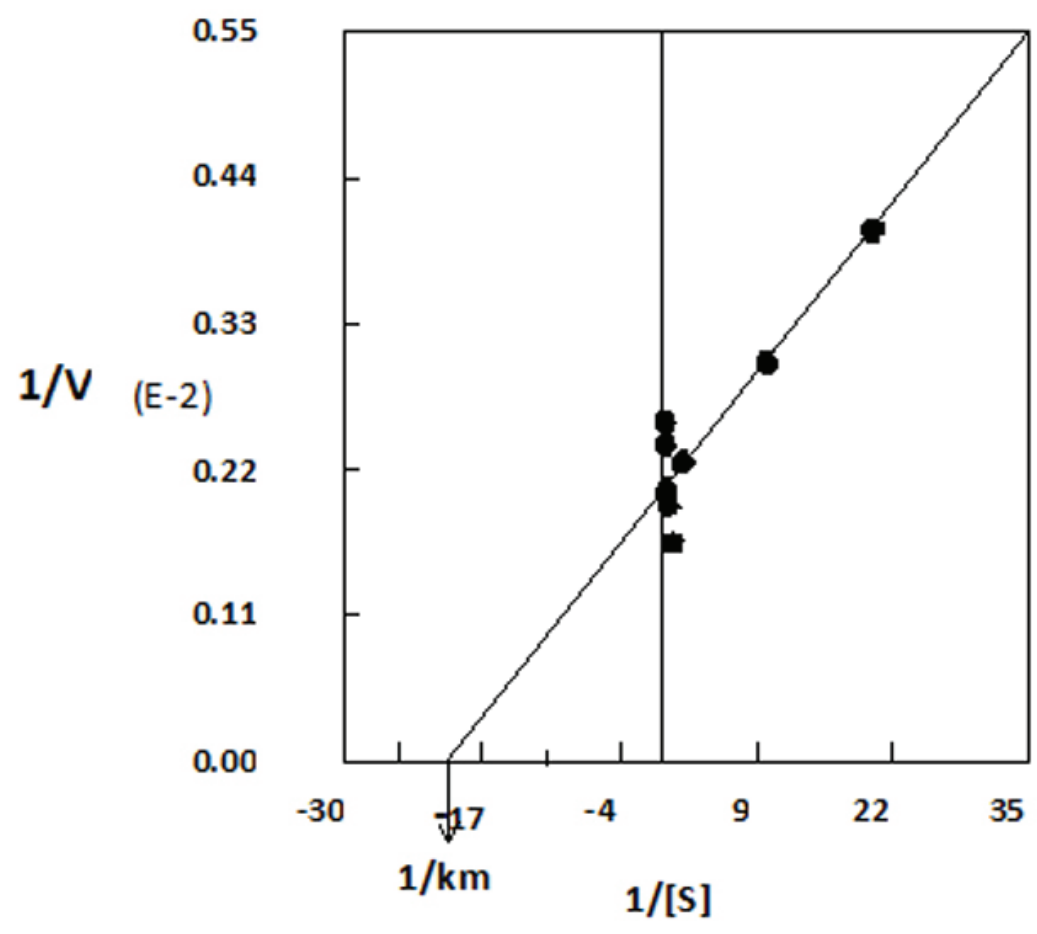

Figure 2. The Lineweaver-Burk plot, representing reciprocal of initial enzyme velocity versus AcSCh concentration for $K_{m}$ determination. $K_{m} 0.068 \mathrm{mM} ; V_{\max }=651 \mu \mathrm{mol} / \mathrm{min} / \mathrm{mg}$ protein.
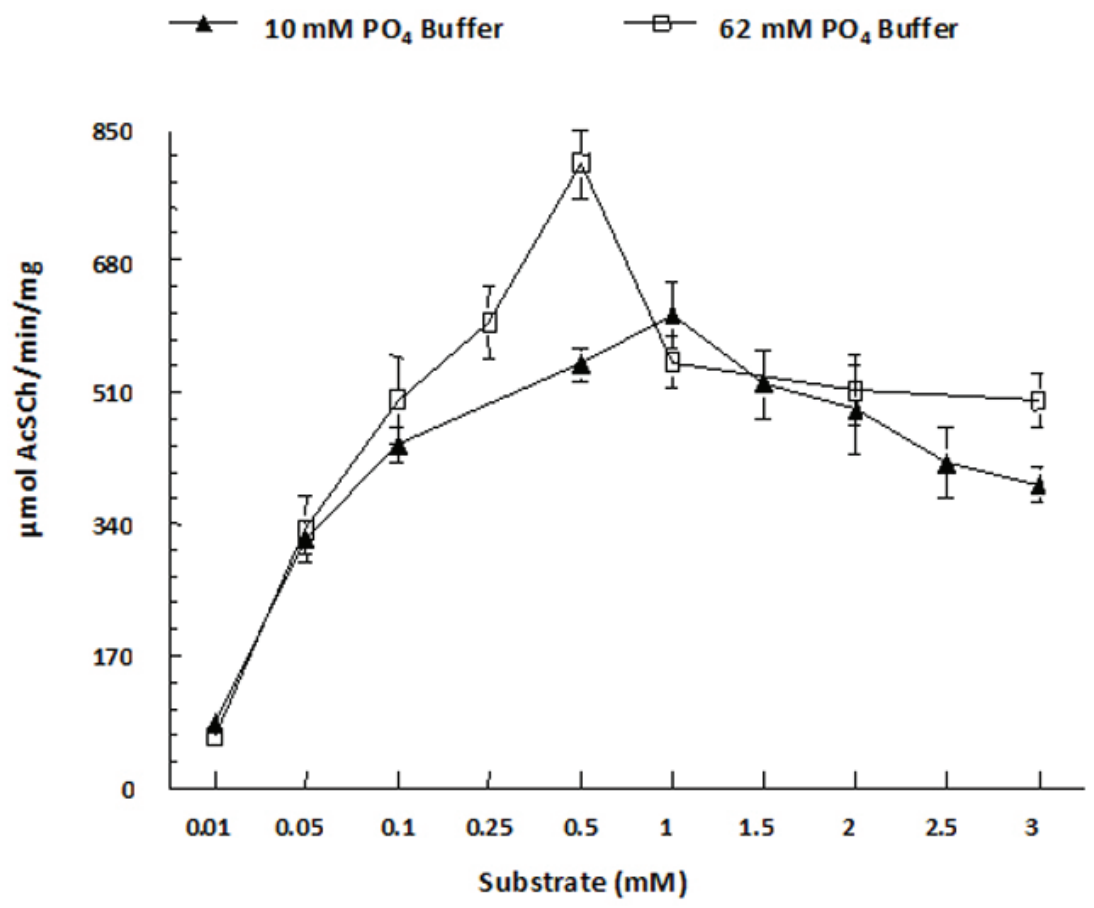

Figure 3. Reduction of enzyme substrate inhibition in high ionic strength buffer. Hydrolysis of acetylthiocholine in $10 \mathrm{mM} \mathrm{PO}_{4^{\prime}} \mathrm{pH} 7.5$, buffer and $62 \mathrm{mM} \mathrm{PO}_{4^{\prime}} \mathrm{pH} 7.5$, buffer by krait (Bungaraus sindanus) venom $A C h E$. Reduction of substrate inhibition is clearly visible in high ionic strength buffer $\left(62 \mathrm{mM} \mathrm{PO}_{4^{\prime}} \mathrm{pH}\right.$ 7.5). Venom $A C h E$ was incubated in the media for ten minutes at $37^{\circ} \mathrm{C}$ before addition of different substrate concentrations $(0.05-3 \mathrm{mM})$. Results are the mean of four different experiments performed in duplicate. 

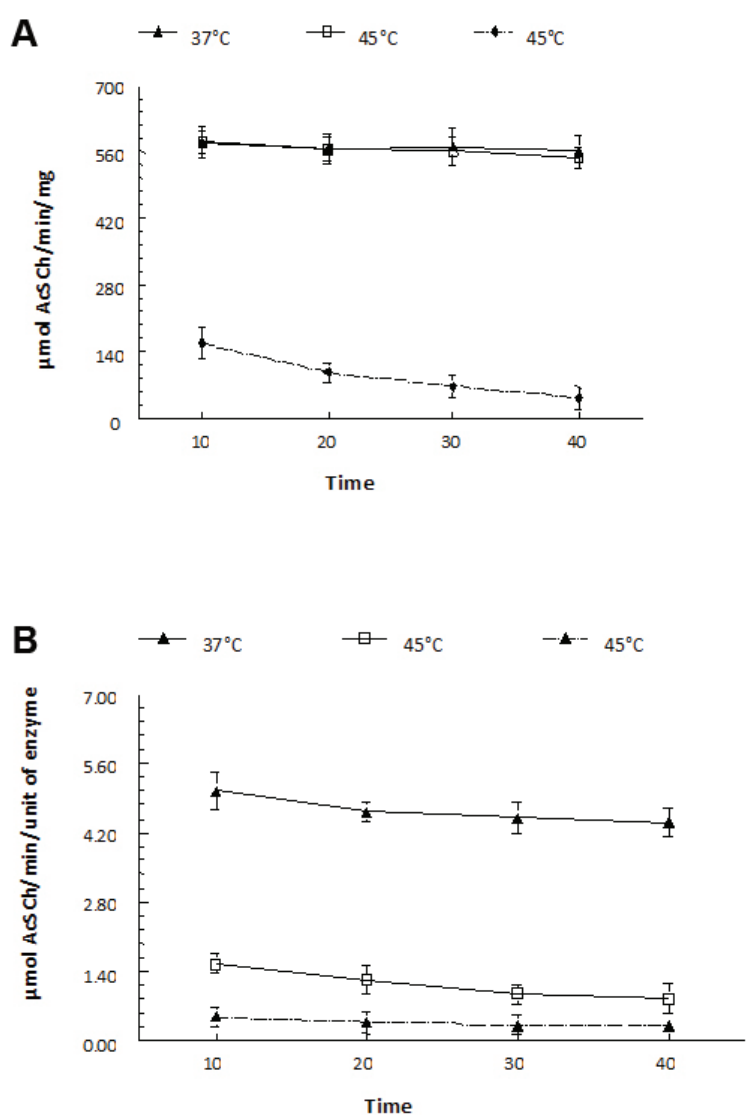

Figure 4. (A) The effect of $\mathrm{pH}$ on enzyme activity was analyzed by incubating the enzyme for ten minutes in different buffers; $10 \mathrm{mM}$ sodium acetate buffer ( $\mathrm{pH} 4$ and 5.5), $10 \mathrm{mM} \mathrm{PO}_{4}$ buffer (pH 6.5 and 7.5), $10 \mathrm{mM}$ Tris- $\mathrm{HCl}$ buffer $(\mathrm{pH} 8.5-10.5)$ at $37^{\circ} \mathrm{C}$ before the addition of $1 \mathrm{mM}$ acetylthiocholine as substrate. Results are the mean of four different experiments and similar results were obtained. The effect of temperature on the enzyme activity was analyzed by incubating the enzyme for ten minutes at different temperature; $25,37,45,50$, and $60^{\circ} \mathrm{C}$ before the addition of $0.2 \mathrm{mM}$ DTNB and 1 $\mathrm{mM}$ acetylthiocholine as a substrate. (B) Results are the mean of four different experiments and similar results were obtained.

\section{DISCUSSION}

In this study, we show that Bungarus sindanus venom has a true AChE, which presents characteristic catalytic properties, as previously reported (23). The Bungarus genus is the richest source of AChE in Elapidae. The optimum substrate concentration was $1 \mathrm{mM}$ using a
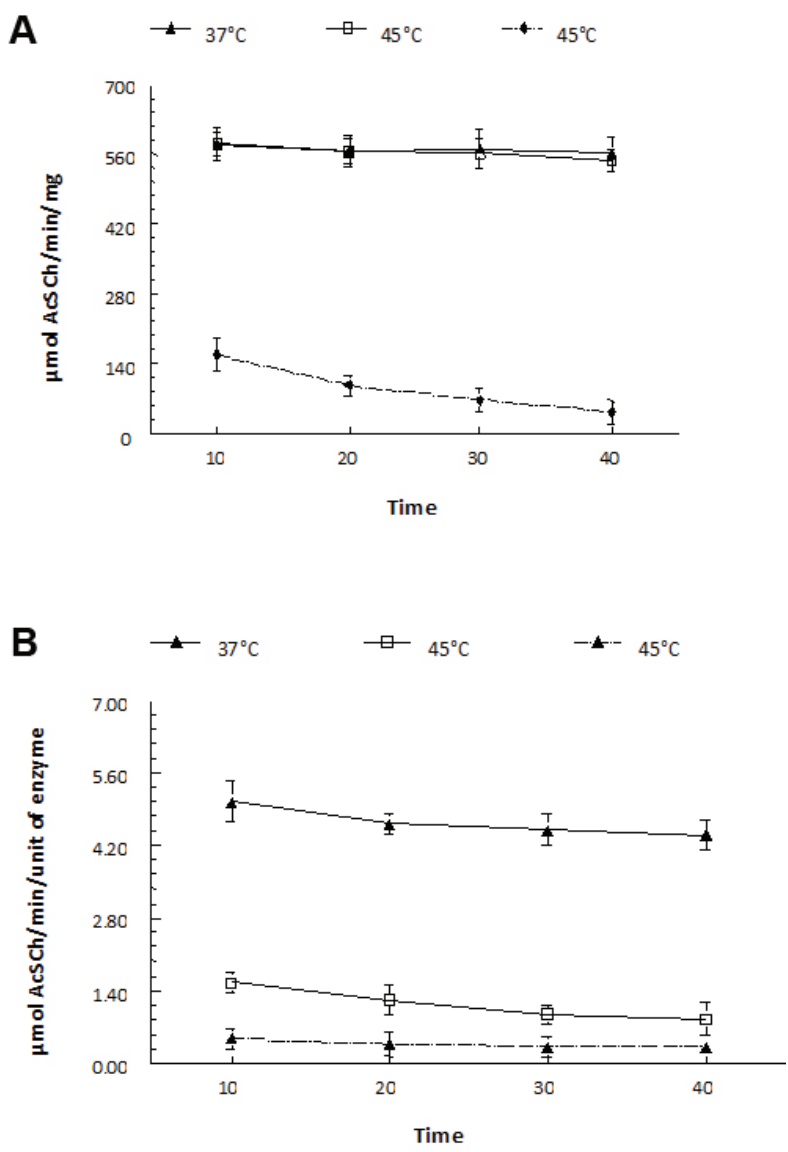

Figure 5. Comparison of thermal stability between (A) krait (Bungarus sindanus) venom $\mathrm{AChE}$ and (B) pure electric eel $A C h E$ incubated at different temperatures $\left(37\right.$ to $50^{\circ} \mathrm{C}$ ) and time intervals (10 to 40 minutes) before the addition of $0.2 \mathrm{mM}$ DTNB and $1 \mathrm{mM}$ acetylthiocholine as substrate.

medium of $10 \mathrm{mM} \mathrm{PO}_{4}$ at $\mathrm{pH} 7.5$ (Figure 1). This concentration is much lower than desert cobra (Walterinnesia aegyptia), in which optimum activity was observed at $3 \mathrm{mM}$ (24). At substrate concentrations greater than $1 \mathrm{mM}$ krait venom AChE hydrolytic property was reduced (Figure 1). Similar substrate inhibition was observed with other snake venom acetylcholinesterase $(10,24$, 25).

Bungararus sindanus AChE was specific for acetylthiocholine, it did not hydrolyze butyrylthiocholine (Figure 1). Snake AChE from all other genera also lacks the ability to hydrolyze butyrylthiocholine (10). The Michaelis-Menten constant $\left(\mathrm{K}_{\mathrm{m}}\right)$ calculated from the LineweaverBurk plot (22) for acetylthiocholine iodide 

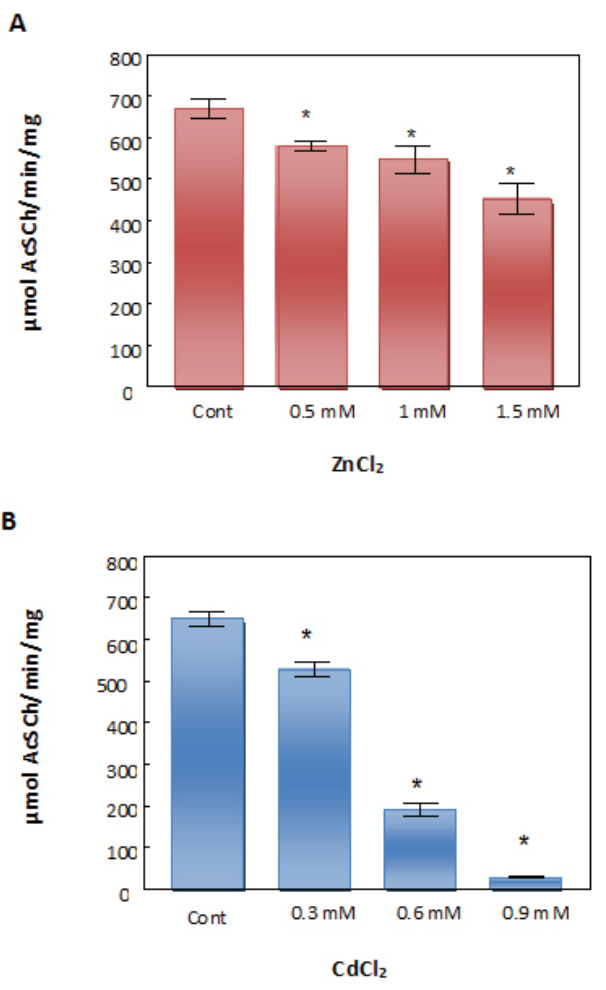

C

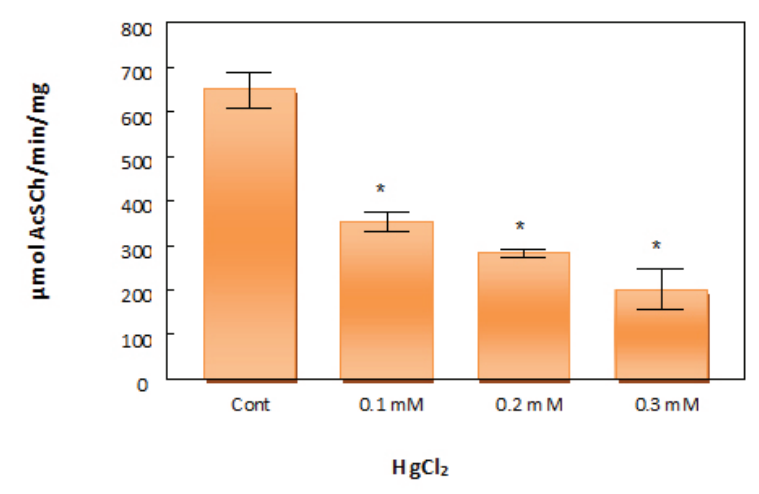

Figure 6. Inhibition of krait (Bungarus sindanus) venom $\mathrm{AChE}$ by metals. Various concentrations of (A) $\mathrm{ZnCl}_{2},(B) \mathrm{CdCl}_{2}$, and (C) $\mathrm{HgCl}_{2}$ were incubated at $37^{\circ} \mathrm{C}$ for ten minutes in $10 \mathrm{mM}$ Tris- $\mathrm{HCl}$ buffer, $\mathrm{pH}$ 8.5. Reactions were started by adding $1 \mathrm{mM}$ acetylcthiocholine (AcSCh) as a substrate. (A) p < 0.029 for $\mathrm{ZnCl}_{2^{\prime}}$ (B) $\mathrm{p}<0.00028$ for $\mathrm{CdCl}_{2^{\prime}}$ and (C) $\mathrm{p}$ $<0.000128$ for $\mathrm{HgCl}_{2}$ compared to control. Results represent the mean of four different experiments performed in duplicate.

hydrolysis was $0.068 \mathrm{mM}$ with $\mathrm{V}_{\max }=651 \mu \mathrm{mol} /$ $\mathrm{min} / \mathrm{mg}$ protein (Figure 2). These values are comparatively higher by Eadie-Hofstee, direct linear, and Wilkinson plots (Table 1).

Bungarus $\mathrm{V}_{\max }$ is very high compared to that of other Elapidae snakes. A significant reduction in krait venom acetylcholinesterase substrate inhibition by high ionic strength buffer was observed. With low ionic strength buffer (10 $\mathrm{mM} \mathrm{PO}_{4}, \mathrm{pH}$ 7.5), the enzyme was inhibited by $1.5 \mathrm{mM}$ AcSCh while with high ionic strength buffer (62 $\left.\mathrm{mM} \mathrm{PO}_{4}, \mathrm{pH} 7.5\right)$ it was inhibited by $1 \mathrm{mM}$ AcSCh (Figure 3). It is worth noting that significant reduction in substrate inhibition with high ionic strength buffer was also mentioned by Frobert et al. (10). Also, the enzyme shows higher activity in high ionic strength buffer $\left(62 \mathrm{mM} \mathrm{PO}_{4}\right.$, $\mathrm{pH} 7.5)$ than in low ionic strength buffer $(10 \mathrm{mM}$ $\mathrm{PO}_{4}, \mathrm{pH} 7.5$ ) (Figure 3).

Bungarus sindanus enzyme shows optimum activity in alkaline $\mathrm{pH}$ (Figure $4-\mathrm{A}$ ). AChE from all other sources also shows higher activity in alkaline media (26). Optimal temperature is $45^{\circ} \mathrm{C}$ (Figure $4-\mathrm{B}$ ), higher than desert cobra (Walterinnesia aegyptia) which shows its highest activity at $30^{\circ} \mathrm{C}(24)$. We also found that krait (Bungarus sindanus) venom acetylcholinesterase is thermally stable at $45^{\circ} \mathrm{C}$. It only lost $5 \%$ of its activity after incubation at $45^{\circ} \mathrm{C}$ for 40 minutes (Figure $5-\mathrm{A}$ ) while at $37^{\circ} \mathrm{C}$ we did not find any loss in its activity (Figure $5-\mathrm{A}$ ). In comparison, electric eel AChE lost $69 \%$ of its activity after 15 minutes at $45^{\circ} \mathrm{C}$ compared to incubation at $37^{\circ} \mathrm{C}$ while after 40 minutes it lost $80 \%$ of its activity (Figure 5 - B).

Generally snake venom $\mathrm{AChE}$ is more stable than other sources. Bungarus snake venom is more stable than Haemacatus, Ophiophagus, and Naja enzymes (10). A thermal stability study of Bungarus AChE by capillary electrophoresis also found that venom AChE is stable under standard conditions (27). Due to its higher activity and stability, this enzyme is very suitable for industrial use. Furthermore, $\mathrm{ZnCl}_{2}, \mathrm{CdCl}_{2}$, and $\mathrm{HgCl}_{2}$ (Figure 6) can also be considered snake venom $\mathrm{AChE}$ inhibitors; however, very high concentrations are necessary. This may be due to the absence of a free sulfhydryl group. According to Frasco et al. (28), when a free sulfhydryl group is absent in the enzyme (Drosophila melonogaster acetylcholinesterase and human serum butyrycholinesterase) inhibition by mercury will occur in the millimolar range, while in the presence of a free sulfhydryl group (Electrophorus electricus), the inhibition will only require a micromolar concentration (28). It is possible that the inhibitory effects of metals on venom acetylcholinesterase are due to the formation of inactive enzyme aggregate (29). 
In conclusion, the Bungarus venom contains large amounts of $\mathrm{AChE}$ with the highest catalytic activity of all sources and is comparatively more stable than any other source, making it a valuable source for biochemical study.

\section{ACKNOWLEDGEMENTS}

The authors are grateful to the Academy of Sciences for the Developing World (TWAS) and the Higher Education Commission of Pakistan for the financial support.

\section{COPYRIGHT}

(C) CEVAP 2012

\section{SUBMISSION STATUS}

Received: December 20, 2012.

Accepted: March 9, 2012.

Abstract published online: March 23, 2012.

Full paper published online: May 31, 2012.

\section{CONFLICTS OF INTEREST}

The authors declare no conflicts of interest.

\section{FINANCIAL SOURCE}

The Academy of Sciences for the Developing World (TWAS) and the Higher Education Commission of Pakistan provided the financial grants.

\section{CORRESPONDENCE TO}

Mushtaq Ahmed, Department of Biotechnology, University of Science and Technology, Bannu, Khyber Pakhtunkhwa, Pakistan. Phone: +92928633425. Email: mushtaq213@yahoo.com.

\section{REFERENCES}

1. Rotundo RL. Expression and localization of acetylcholinesterase at the neuromuscular junction. J Neurocytol. 2003;32(5-8):743-66.

2. Barnard EA. Neuromuscular transmission-enzymatic destruction of acetylcholine. In: Hubbard JI, editor. The peripheral nervous system. New York: Plenum Press; 1974. p. 201-24.

3. Quinn DM. Acetylcholinesterase: enzyme structure, reaction dynamics, and virtual transition state. Chem Rev. 1987;87(5):955-79.

4. Rosenberry TL. Acetylcholinesterase. In: Meister A, editor. Advances in Enzymology. New York: John Wiley \& Sons; 1975. p. 43.

5. Drews U. Cholinesterase in embryonic development. Prog Histochem Cytochem. 1975;7(3):1-52.

6. Layer PG, Girgert R, Rommel S, Spoms O. Development of embryonic cholinesterases and cell proliferation in chicken brain and retina. J Neurochem. 1985;44:12931.

7. Layer PG, Alber R, Rathjen FG. Sequential activation of butyrylcholinesterase in rostral half somites and acetylcholinesterase in motoneurones and myotomes preceding growth of motor axons. Development. 1988;102(2):387-96.

8. Kawashima K, Fujii T. Extraneuronal cholinergic system in lymphocytes. Pharmacol Ther. 2000;86(1):29-48.

9. Thiermann H, Szinicz L, Eyer P, Zilker T, Worek F. Correlation between red blood cell acetylcholinesterase and neuromuscular transmission in organophosphate poisoning. Chem Biol Interact. 2005;157-158:345-7.

10. Frobert Y, Créminon C, Cousin X, Rémy $M$, Chatel J, Bon S, et al. Acetylcholinesterases from Elapidae snake venoms: biochemical, immunological and enzymatic characterization. Biochim Biophys Acta. 1997;1339(2):253-67.

11. Iwanaga S, Suzuki T. Enzymes in snake venom. In: Lee CY, editor. Handbook of Experimental Pharmacology. Vol. 52. New York: Springer-Verlag; 1979. p. 61-158.

12. Bawaskar HS, Bawaskar PH. Envenoming by the common krait (Bungarus sindanus) and Asian cobra (Naja naja): clinical manifestations and their management in a rural setting. Wilderness Environ Med. 2004;15(4):257-66.

13. Mackessy SP, Sixberry NM, Heyborne WH, Fritts T. Venom of the brown treesnake, Boiga irregularis: ontogenetic shifts and taxa-specific toxicity. Toxicon. 2006;47(5):537-48.

14. Cousin X, Créminon C, Grassi J, Méflah K, Cornu G, Saliou B, et al. Acetylcholinesterase from Bungarus venom: a monomeric species. FEBS Lett. 1996;387(23):196-200.

15. Rosenberry TL, Johnson JL, Cusack B, Thomas JL, Emani S, Venkatasubban KS. Interactions between the peripheral site and the acylation site in acetylcholinesterase. Chem Biol Interact. 2005;157158:181-9.

16. Szegletest T, Mallander WD, Thomas PJ, Rosenberry TL. Substrate binding to the peripheral site of acetylcholinesterase initiates enzymatic catalysis: substrate inhibition arises as a secondary effect. Biochemestry. 1999;38(1):122-33.

17. Ahmed M, Rocha JB, Mazzanti CM, Morsch AL, Cargnelutti D, Corrêa M, et al. Malathion, carbofuran and paraquat inhibit Bungarus sindanus (krait) venom acetylcholinesterase and human serum butyrylcholinesterase in vitro. Ecotoxicology. 2007;16(4):363-9.

18. Ahmed M, Rocha JB, Corrêa M, Mazzanti CM, Zanin $\mathrm{RF}$, Morsch AL, et al. Inhibition of two different cholinesterases by tacrine. Chem Biol Interact. 2006;162(2):165-71.

19. Bradford MM. A rapid and sensitive method for the quantification of microgram quantities of protein utilizing the principle of protein dye binding. Anal Biochem. 1976;72:248-54.

20. Ellman GL, Courtney KD, Andres JRV, Feather-Stone RM. A new and rapid colorimetric determination of 
acetylcholinesterase activity. Biochem Pharmacol. 1961;7:88-95.

21. Ahmed M, Batista J, Rocha T, Mazzanti CM, Hassan W, Morsch VM, et al. Comparative study of the inhibitory effect of antidepressants on cholinesterase activity in Bungarus sindanus (krait) venom, human serum and rat striatum. J Enzyme Inhib Med Chem. 2008;23(6):912-7.

22. Lineweaver $\mathrm{H}$, Burk $\mathrm{D}$. The determination of enzyme dissociation constants. J Am Chem Soc. 1934;56(3):658-66.

23. Kumar V, Elliott WB. The acetylcholinesterase of Bungarus fasciatus venom. Eur J Biochem. 1973;34(3):586-92.

24. Aljafari AA, Kamal MA, Duhaiman AS, Alhomida AS. Acetylcholinesterase from desert cobra (Walterinnesia aegyptia) venom. optimization and kinetics study. Mol Cell Biochem. 1995;151(1):21-6.

25. Kreienkamp HJ, Weise C, Raba R, Aaviksaar A, Hucho F. Anionic subsites of the catalytic center of acetylcholinesterase from torpedo and from cobra venom. Proc Natl Acad Sci USA. 1991;88(14):6117-21.
26. Aliriz S, Turkoglu V. Purification and Characterization of acetylcholinesterase from the Lake Van fish (Chalcalburnus tarichii Pallas, 1811). Prep Biochem Biotechnol. 2003;33(2):137-45.

27. Rochu D, Georges C, Répiton J, Viguié DN, Bon C, Masson P. Thermal stability of acetylcholinesterase from Bungarus fasciatus venom as investigated by capillary electrophoresis. Biochim Biophys Acta. 2001;1545(1-2):216-26.

28. Frasco MF, Colletier JP, Weike M, Carvalho F, Guilhermino L, Stojan J, et al. Mechanism of cholinesterase by inorganic mercury. FEBS J. 2007;274(7):1849-61.

29. Lee AM, Singleton SF. Inhibition of the Escherichia coli RecA protein: zinc (II), copper(II) and mercury(II) trap RecA as inactive aggregates. J Inorg Biochem. 2004;98(11):1981-6. 